\title{
Involvement of $\mathrm{AT}_{1}$ angiotensin receptors in the vasomodulatory effect of des-aspartate-angiotensin I in the rat renal vasculature
}

\author{
M. Dharmani ${ }^{a}$, M.R. Mustafa ${ }^{a, *}$, F.I. Achike ${ }^{b}$, M.K. Sim ${ }^{c}$ \\ a Department of Pharmacology, Faculty of Medicine, University of Malaya, 50603 Kuala Lumpur, Malaysia \\ ${ }^{\mathrm{b}}$ Clinical Sciences Section, International Medical University, Sesama Centre, Bukit Jalil, 57000 Kuala Lumpur, Malaysia \\ ${ }^{\mathrm{c}}$ Department of Pharmacology, Yong Loo Lin School of Medicine, Building MD11, 10 Medical Drive, University of Singapore, \\ 117597 Singapore City, Singapore
}

\section{A R T I C L E I N F O}

\section{Article history:}

Received 27 March 2008

Received in revised form

13 May 2008

Accepted 20 May 2008

Published on line 28 May 2008

\section{Keywords:}

Angiotensin subtype 1 receptor

Des-aspartate angiotensin I

Renal vasculature

Streptozotocin-induced diabetes

Spontaneously hypertensive rat

\begin{abstract}
A B S T R A C T
Angiotensin II is known to act primarily on the angiotensin $\mathrm{AT}_{1}$ receptors to mediate its physiological and pathological actions. Des-aspartate-angiotensin I (DAA-I) is a bioactive angiotensin peptide and have been shown to have contrasting vascular actions to angiotensin II. Previous work in this laboratory has demonstrated an overwhelming vasodepressor modulation on angiotensin II-induced vasoconstriction by DAA-I. The present study investigated the involvement of the $\mathrm{AT}_{1}$ receptor in the actions of DAA-I on angiotensin IIinduced vascular actions in the renal vasculature of normotensive Wistar-Kyoto rats (WKY), spontaneously hypertensive rats (SHR) and streptozotocin (STZ)-induced diabetic rats. The findings revealed that the angiotensin receptor in rat kidney homogenate was mainly of the $\mathrm{AT}_{1}$ subtype. The $\mathrm{AT}_{1}$ receptor density was significantly higher in the kidney of the SHR. The increase in $\mathrm{AT}_{1}$ receptor density was also confirmed by RT-PCR and Western blot analysis. In contrast, $\mathrm{AT}_{1}$ receptor density was significantly reduced in the kidney of the streptozotocininduced diabetic rat. Perfusion with $10^{-9} \mathrm{M}$ DAA-I reduced the $\mathrm{AT}_{1}$ receptor density in the kidneys of WKY and SHR rats suggesting that the previously observed vasodepressor modulation of the nonapeptide could be due to down-regulation or internalization of $\mathrm{AT}_{1}$ receptors. RT-PCR and Western blot analysis showed no significant changes in the content of $\mathrm{AT}_{1}$ receptor mRNA and protein. This supports the suggestion that DAA-I causes internalization of $\mathrm{AT}_{1}$ receptors. In the streptozotocin-induced diabetic rat, no significant changes in renal $\mathrm{AT}_{1}$ receptor density and expression were seen when its kidneys were similarly perfused with DAA-I.
\end{abstract}

(C) 2008 Elsevier Inc. All rights reserved.

\section{Introduction}

The RAS plays an important role in the regulation of blood pressure and fluid homeostatis and exerts this effect through the production of angiotensin II. Angiotensin II increases the renal vascular resistance by constricting afferent and efferent arterioles including interlobular arteries [6]. The effects of angiotensin II are mediated through high-affinity membrane bound receptors, classified as $\mathrm{AT}_{1}$ and $\mathrm{AT}_{2}$ receptor subtypes. Most of the known effects of angiotensin II have been attributed to the $\mathrm{AT}_{1}$ receptor. In the kidney, $\mathrm{AT}_{1}$ receptors are present in the preglomerular arteries and arterioles,

\footnotetext{
* Corresponding author. Fax: +60 379674791.

E-mail address: rais@um.edu.my (M.R. Mustafa). 
glomeruli, vasa rectae and proximal convoluted tubules [8]. In addition, angiotensin II plays a key role in the initiation and amplification of pathobiological events that underlie several vascular diseases. The findings of other bioactive angiotensin peptides, i.e., DAA-I and angiotensin-(1-7) with contrasting vascular actions to angiotensin II has generated interest in the pleiotropism of the $\mathrm{AT}_{1}$ receptor and other receptor subtypes that mediate their actions.

Angiotensin peptides may bind to multiple angiotensin receptor subtypes that often exhibit different and sometimes opposing actions. For example, angiotensin II has been shown to bind to both $\mathrm{AT}_{1}$ and $\mathrm{AT}_{2}$ receptor subtype which are coupled to specific effector systems that elicit different biological responses. DAA-I, has been shown to have cardioprotective action by modulating the expression the $\mathrm{AT}_{1}$ and $\mathrm{AT}_{2}$ receptor differentially to attenuate cardiac hypertrophy in rats with abdominal aortic coarctation [9]. This nonapeptide has also been demonstrated to prevent myocardial infact expansion through suppression of inflammatory cytokines and immune cell infiltration [1]. Studies with rabbit [31] and rat aortic rings [19], and rabbit pulmonary artery [30] demonstrated that DAA-I acts as an agonist on losartan-sensitive angiotensin receptor.

In a recent study, we observed increased contractile responses to angiotensin II in the kidney of SHR rats and decreased responses in the kidney of STZ-induced diabetic rat, and suggested that the differences could be due to changes in the angiotensin receptor density [13]. We also demonstrated that DAA-I had a vasodepressing action on the contractile action of angiotensin II in the WKY and SHR renal vasculature and ruled out the involvement of $\mathrm{AT}_{2}$ receptor in mediating the observed responses [13]. As an extension of the earlier investigation, the present study investigated the effect of DAA-I on the profile of renal $\mathrm{AT}_{1}$ receptors in the WKY, SHR and STZ-induced diabetic rats.

\section{Methodology}

\subsection{Animals}

Male Wistar-Kyoto (WKY) rats and spontaneously hypertensive rats (SHRs) weighing 250-300 g (11-12 weeks) were obtained from Animal House in the University of Malaya Medical Centre. The animals were fed standard rat chow and tap water ad libitum.

\subsection{Induction of diabetes}

WKY was made diabetic by administration of streptozotocin (STZ) $75 \mathrm{mg} / \mathrm{kg}$ intraperitoneally. Age matched controls received equal volume of vehicle. Prior to injection, animal weights and blood glucose levels were recorded. Body weights and blood glucose were taken every 2 weeks until the 8 th week. Animals were considered diabetic if their blood glucose concentration was $>17 \mathrm{mM}$.

In our earlier part of the work [13], DAA-I was perfused through the kidney and the possibility was considered that this peptide acted on the angiotensin receptors present on the membrane of any part of the whole kidney. Thus, we used the whole kidney in the current study.

\subsection{Receptor binding assay}

The right kidney from WKY, SHR and STZ-induced diabetic rats were isolated and perfused with Krebs solution containing only captopril $(30 \mu \mathrm{M})$ (control) or captopril and DAA-I $\left(10^{-9} \mathrm{M}\right.$ to $10^{-15} \mathrm{M}$ ) for $90 \mathrm{~min}$ prior to its use for the preparation of kidney membranes. At these concentrations, DAA-I was effective in attenuating the contraction of kidney vasculature induced by angiotensin II [13]. Kidney membrane was prepared as described by Brown et al. [5] with slight modification. Briefly, each kidney was minced into small pieces and suspended 1:10 (w/v) in Tris-HCl buffer $(50 \mathrm{mM}, \mathrm{pH}$ 7.4), homogenized and the homogenate was centrifuged at $30,000 \times \mathrm{g}$ at $4{ }^{\circ} \mathrm{C}$ for $40 \mathrm{~min}$. The resultant pellet was resuspended and recentrifuged twice under the same conditions. The final pellet was resuspended in Tris- $\mathrm{HCl}(20 \mathrm{mM}, \mathrm{pH}$ 7.4), containing $\mathrm{NaCl}(135 \mathrm{mM}), \mathrm{KCl}(10 \mathrm{mM})$, glucose $(5 \mathrm{mM})$ and $\mathrm{MgCl}_{2}(10 \mathrm{mM})$. Protein concentration was determined using the Biuret assay. The prepared membranes were kept as aliquots at $-80^{\circ} \mathrm{C}$ for not longer than 3 months.

The displacement radioligand binding experiment was carried out using the homologous competitive binding method described by Brown et al. [5] with slight modification. Each aliquot of membrane suspension equivalent to $40 \mu \mathrm{g}$ of protein was added to a solution of ${ }^{125} \mathrm{I}_{-} \mathrm{Sar}^{1}-\mathrm{Ile}^{8}$-Ang II (2.3$2.5 \times 10^{4}$ c.p.m.) together with a different (increasing) concentration of non-radioactive Sar ${ }^{1}-\mathrm{Ile}^{8}$-Ang II $(0.0001-300 \mathrm{nM})$ in $300 \mu \mathrm{l}$ of $50 \mathrm{mM}$ Tris-HCl buffer ( $\mathrm{pH} 7.4)$ containing $0.3 \mathrm{mM}$ phenylmethylsulphonyl fluoride (PMSF), $0.1 \mathrm{mM}$ bacitracin and $0.2 \%$ bovine serum albumin (BSA). The assay mixture was incubated at $22{ }^{\circ} \mathrm{C}$ for $2 \mathrm{~h}$ with continuous shaking. The bound and unbound ligand was separated by addition of cold bovine gamma globulin and polyethylene glycol and centrifugation at $5000 \times g$ and $4{ }^{\circ} \mathrm{C}$ for $40 \mathrm{~min}$. The radioactivity trapped in the pellets was counted using a gamma counter (Wizard Gamma Counter, PerkinElmer). Efficiency of the counter was $95 \%$. Receptor density was calculated using Graph Pad Prism software. The assay was conducted in duplicate and repeated three to four times per group.

\subsection{Semi-quantitative reverse-transcriptase polymerase chain reaction (RT-PCR)}

The right kidneys from WKY, SHR and STZ-induced diabetic rats were isolated and perfused with Krebs and captopril $(30 \mu \mathrm{M})$ (control) or with DAA-I $\left(10^{-9} \mathrm{M}\right.$ to $\left.10^{-15} \mathrm{M}\right)$ for $90 \mathrm{~min}$. The kidneys were frozen in liquid nitrogen and kept at $-80^{\circ} \mathrm{C}$ for further RNA isolation. Total RNA was isolated from the kidneys using Reagent ${ }^{\circledR}$ system according to the manufacturer's instructions. The tissue (100 mg) was homogenized in the provided denaturing solution. Two molar sodium acetate (pH 4) was then added, followed by phenol:chloroform:isamyl alcohol. This mixture was then kept in ice for $15 \mathrm{~min}$ before centrifuging at $10,000 \times \mathrm{g}$ for $20 \mathrm{~min}$ at $4^{\circ} \mathrm{C}$. After centrifugation, the top aqueous phase containing the RNA was carefully removed and equal volume of isopropanol was added to the aqueous phase and incubated at $-20^{\circ} \mathrm{C}$ to allow precipitation of RNA. The RNA was pelleted by ultracentrifugation and was washed in ice-cold 75\% ethanol, re-pelleted and dissolved in nuclease-free water. The amount of RNA was quantified by 
absorbance at $260 \mathrm{~nm}$ and stored at $-20{ }^{\circ} \mathrm{C}$ for not more than 6 months.

cDNA was synthesized using Revertaid ${ }^{\mathrm{TM}} \mathrm{H}$ Minus First Strand cDNA Synthesis Kit, according to the manufacturer's protocols. One microlitre of $0.5 \mu \mathrm{g} / \mu \mathrm{l}$ oligo $(\mathrm{dT})_{18}$ primer was added to $1 \mu \mathrm{g}$ of total RNA. The final total volume was $12 \mu \mathrm{l}$. The mixture was mixed gently, spun down and incubated at $70{ }^{\circ} \mathrm{C}$ for $5 \mathrm{~min}$. Then, $4 \mu \mathrm{l}$ of $5 \times$ reaction buffer, $1 \mu \mathrm{l}$ of RiboLock ${ }^{\mathrm{TM}}$ Ribonuclease inhibitor $(20 \mathrm{U} / \mu \mathrm{l})$, and $2 \mu \mathrm{l}$ of $10 \mathrm{mM}$ dNTP mix were added to the mixture and spun down. The mixture was incubated at $37^{\circ} \mathrm{C}$ for $5 \mathrm{~min}$. Lastly, $1 \mu \mathrm{l}$ of RevertAidTM $\mathrm{H}$ Minus $\mathrm{M}-\mathrm{MuLV}$ reverse trancriptase was added and the mixture incubated at $42^{\circ} \mathrm{C}$ for $60 \mathrm{~min}$. The reaction was stopped by heating at $70^{\circ} \mathrm{C}$ for $10 \mathrm{~min}$. The synthesized cDNA was kept at $-20^{\circ} \mathrm{C}$.

One microlitre of synthesized cDNA was added to the reaction mixture containing reaction buffer, $0.2 \mu \mathrm{M}$ of each of the two primers, $2 \mathrm{mM} \mathrm{MgCl}_{2}, 0.2 \mathrm{mM}$ of each dNTP and $1.25 \mathrm{U}$ of Taq polymerase. The final volume was $25 \mu$ l. The mixture was spun down and placed in the thermal cycler (PTC-200, MJ Research). After denaturation at $95^{\circ} \mathrm{C}$ for $15 \mathrm{~min}$, amplification cycles of $94^{\circ} \mathrm{C}, 60^{\circ} \mathrm{C}$ and $72{ }^{\circ} \mathrm{C}$ for $30 \mathrm{~s}$ were performed. Final elongation was carried out at $72^{\circ} \mathrm{C}$ for $2 \mathrm{~min}$. GADPH was chosen as the internal standard. The PCR products were electrophoresed using 1.5\% agarose gel containing ethidium bromide $0.5 \mu \mathrm{g} / \mathrm{ml}$. The gel was subjected to ultraviolet light, photographed (Kodak Digital Science) and analyzed.

\begin{tabular}{llll}
\hline & Primer $\left(5^{\prime}-3^{\prime}\right)$ & $\begin{array}{l}\text { PCR } \\
\text { cycle }\end{array}$ & $\begin{array}{l}\text { Size } \\
(\mathrm{bp})\end{array}$ \\
\hline $\mathrm{AT}_{1}$ & $\begin{array}{l}\text { Fwd: ATCTCGCCTTGGCTGACTTA; } \\
\text { Rvs: GACTTCATTGGGTGGACGA }\end{array}$ & 35 & 200 \\
$\mathrm{~F}$ GADPH & $\begin{array}{l}\text { Fwd: GGTGCTGAGTATGTCGTG; } \\
\text { Rvs: TTCAGCTCTGGGATGACC }\end{array}$ & 35 & 400 \\
\hline
\end{tabular}

List of primers used in semi-quantitative RT-PCR.

\subsection{Western blotting}

The right kidneys from WKY, SHR and STZ-induced diabetic rats were isolated and perfused with Krebs and captopril $(30 \mu \mathrm{M})$ (control) or with DAA-I $\left(10^{-9} \mathrm{M}\right.$ to $\left.10^{-15} \mathrm{M}\right)$ for $90 \mathrm{~min}$ prior to the homogenate preparation. Tissue homogenate was prepared according to the method described by Zelezna et al. [36] with slight modification. Kidneys were homogenized in phosphate-buffered saline (PBS) containing protease inhibitors $(30 \mu \mathrm{g}$ PMSF, $300 \mu \mathrm{g}$ EDTA, and $0.5 \mu \mathrm{g}$ bacitracin/ml). Homogenates were centrifuged at $20,000 \times g$ for $10 \mathrm{~min}$, and pellets were re-suspended in PBS with protease inhibitors and rinsed twice by centrifugation. Final pellet were re-suspended and protein concentration were determined using Biuret assay. The supernatant was heated to $95^{\circ} \mathrm{C}$ for $5 \mathrm{~min}$ in the presence of $2 \times$ treatment buffer $(0.125 \mathrm{M}$ Tris-HCl, $4 \%$ SDS, $20 \%$ glycerol, $0.2 \mathrm{M} \mathrm{DTT}, 0.02 \%$ Bromophenol blue, $\mathrm{pH}$ 6.8).

The protein $(80 \mu \mathrm{g})$ was resolved on a $12.5 \%$ SDS-PAGE and transferred to polyvinylidene difluoride (PVDF) membrane. The blotted PVDF membrane was saturated with $3 \%$ gelatin in PBS, pH 7.4 containing $0.1 \%$ Tween-20 for $1 \mathrm{~h}$ at room temperature to block non-specific binding. The membrane was then sequentially incubated with $\mathrm{AT}_{1}$ receptor antibody (Santa Cruz Biotechnology, 1:1100) overnight at $4{ }^{\circ} \mathrm{C}$, washed with Tris-buffered saline containing $0.1 \%$ Tween-20 and followed by incubation with goat anti-rabbit IgG-HRP conjugated (1:1300) for $2 \mathrm{~h}$ at room temperature. After thorough washing, the blot was developed by incubating with HRPcomplex until the bands have adequate intensity. The blot was dried, scanned and analyzed.

\subsection{Statistical analysis}

Data were expressed as mean \pm S.E.M. One-way ANOVA and Dunnett post hoc test were employed to determine the significance differences, with an accepted level of significance of $p<0.05$. $B_{\max }$ and $K_{d}$ value for receptor binding were determined using the homologous competitive equation (GraphPad Prism). The band intensities for RT-PCR and Western blot were measured using a software package (Scion image). The signals for RT-PCR were expressed relative to the intensity of the GADPH amplicon for each co-amplified sample.

\section{Results}

\subsection{Receptor binding assay}

The binding of ${ }^{125} \mathrm{I}_{-} \mathrm{Sar}^{1}-\mathrm{Il} \mathrm{e}^{8}$-Ang II to the rat kidney membranes was displaced by losartan and Sar $^{1}-I l e^{8}$-Ang II in a concentration-dependent manner with an almost $100 \%$ displacement at $10^{-7} \mathrm{M}$ concentration (Fig. 1). On the other hand, $\mathrm{PD} 123319$, an $\mathrm{AT}_{2}$ receptor antagonist, displaced less than $30 \%$ of the labelled ligand at $10^{-6} \mathrm{M}$. This shows that the kidney membranes contain mainly $\mathrm{AT}_{1}$ receptors and a very small proportion of $\mathrm{AT}_{2}$ receptors. Renal $\mathrm{AT}_{1}$ receptor density was significantly higher in SHR $(739.6 \pm 44.0 \mathrm{fmol} / \mathrm{mg})$ and lower in STZ-induced diabetic $(271.5 \pm 34.94 \mathrm{fmol} / \mathrm{mg})$ compared to WKY $(430.0 \pm 8.12 \mathrm{fmol} / \mathrm{mg})$ (Fig. 2). $\mathrm{AT}_{1}$ binding affinity $\left(\mathrm{K}_{\mathrm{d}}\right)$ between WKY, SHR and STZ-induced diabetic rats were not significantly different (Table 1).

In functional studies reported earlier [13], the involvement of $\mathrm{AT}_{2}$ receptor in the vasomodulatory role of DAA-I was excluded. Thus, subsequent experiments were focused on

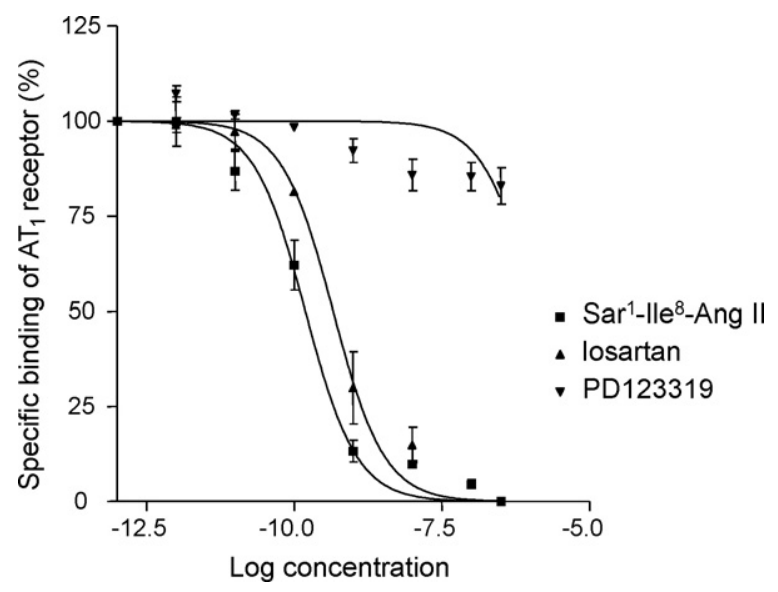

Fig. 1 - Displacement of ${ }^{125} \mathrm{I}_{-} \mathrm{Sar}^{1}-\mathrm{Ile}^{8}$-Ang II by losartan $(\square)$, Sar-Ile-Ang II ( $\Delta)$ and PD123319 $(\nabla)$ in kidney membrane preparations of untreated rats (control). 


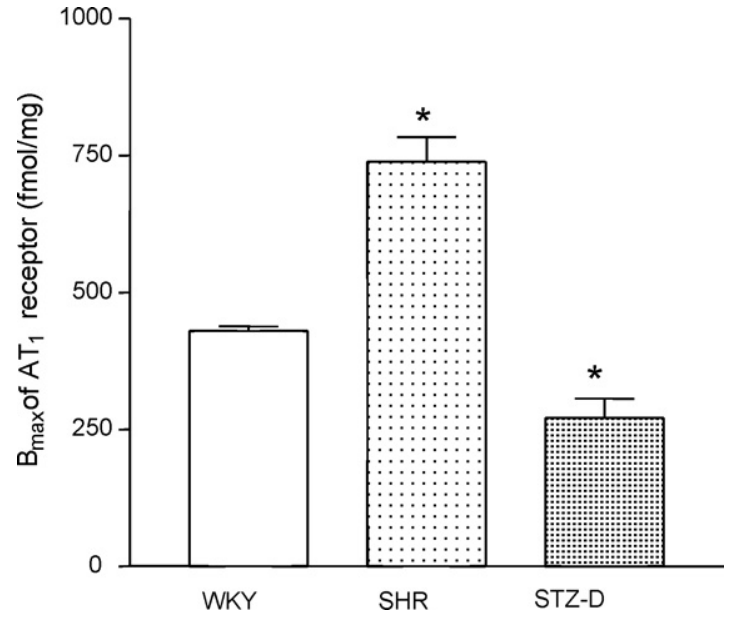

Fig. 2 - Maximal binding capacity of [ $\left.{ }^{125} \mathrm{I}\right]-\mathrm{Sar}^{1}-\mathrm{Ile} \mathrm{e}^{8}$-Ang II $\left(B_{\text {max }}\right)$ in kidney membranes of WKY-, SHR- and STZtreated rats. Bars represent the mean value \pm S.E.M. of at least four experiments performed in duplicates. *Indicates significant difference from WKY $(p<0.05)$.

evaluating the involvement of the $\mathrm{AT}_{1}$ receptors. Pretreatment with $10^{-9} \mathrm{M}$ DAA-I caused a significant reduction in renal $\mathrm{AT}_{1}$ receptor density in WKY and SHR rats (Fig. 3). DAA-I does not affect the receptor density of $\mathrm{AT}_{1}$ receptor in the STZ-induced diabetic rat kidney (Fig. 3). DAA-I did not affect the $K_{d}$ of $A_{1}$ receptor for the iodinated ligand in renal membranes of the three different groups of rats (Table 1).

\subsection{RT-PCR}

The mRNA expression of $\mathrm{AT}_{1}$ receptors in the kidneys of WKY, SHR and STZ-induced diabetic rats is shown in Fig. 4. GADPH was used as an internal standard. The densitometic values of the $\mathrm{AT}_{1}$ receptor were normalized against the corresponding GADPH values. Compared to the WKY, there was an increase in renal $\mathrm{AT}_{1}$ receptor mRNA in the SHR (1.051 \pm 0.066 vs. $0.794 \pm 0.067$, SHR and WKY, respectively) and a decrease in the STZ-induced diabetic rats $(0.592 \pm 0.052$ vs. $0.794 \pm 0.067$,

\begin{tabular}{lc}
\multicolumn{2}{l}{ Table 1 - Homologous competitive binding parameters } \\
Groups & $\mathrm{K}_{\mathrm{d}}$ value $(\mathrm{nM})$ \\
\hline WKY & $1.187 \pm 0.068$ \\
DAA-I $\left(10^{-9} \mathrm{M}\right)$ & $0.889 \pm 0.092$ \\
DAA-I $\left(10^{-12} \mathrm{M}\right)$ & $1.012 \pm 0.152$ \\
DAA-I $\left(10^{-15} \mathrm{M}\right)$ & $1.465 \pm 0.182$ \\
SHR & $1.440 \pm 0.125$ \\
DAA-I $\left(10^{-9} \mathrm{M}\right)$ & $1.284 \pm 0.140$ \\
DAA-I $\left(10^{-12} \mathrm{M}\right)$ & $1.680 \pm 0.136$ \\
DAA-I $\left(10^{-15} \mathrm{M}\right)$ & $1.638 \pm 0.143$ \\
STZ-induced diabetic & $0.784 \pm 0.229$ \\
DAA-I $\left(10^{-9} \mathrm{M}\right)$ & $0.931 \pm 0.194$ \\
DAA-I $\left(10^{-12} \mathrm{M}\right)$ & $0.864 \pm 0.196$ \\
DAA-I $\left(10^{-15} \mathrm{M}\right)$ & $1.315 \pm 0.277$
\end{tabular}

Values are expressed as mean \pm S.E.M. of 3-4 binding experiments. $B_{\max }$ values are in $\mathrm{fmol} / \mathrm{mg}$ protein; $K_{d}$ values are in $\mathrm{nM}$.
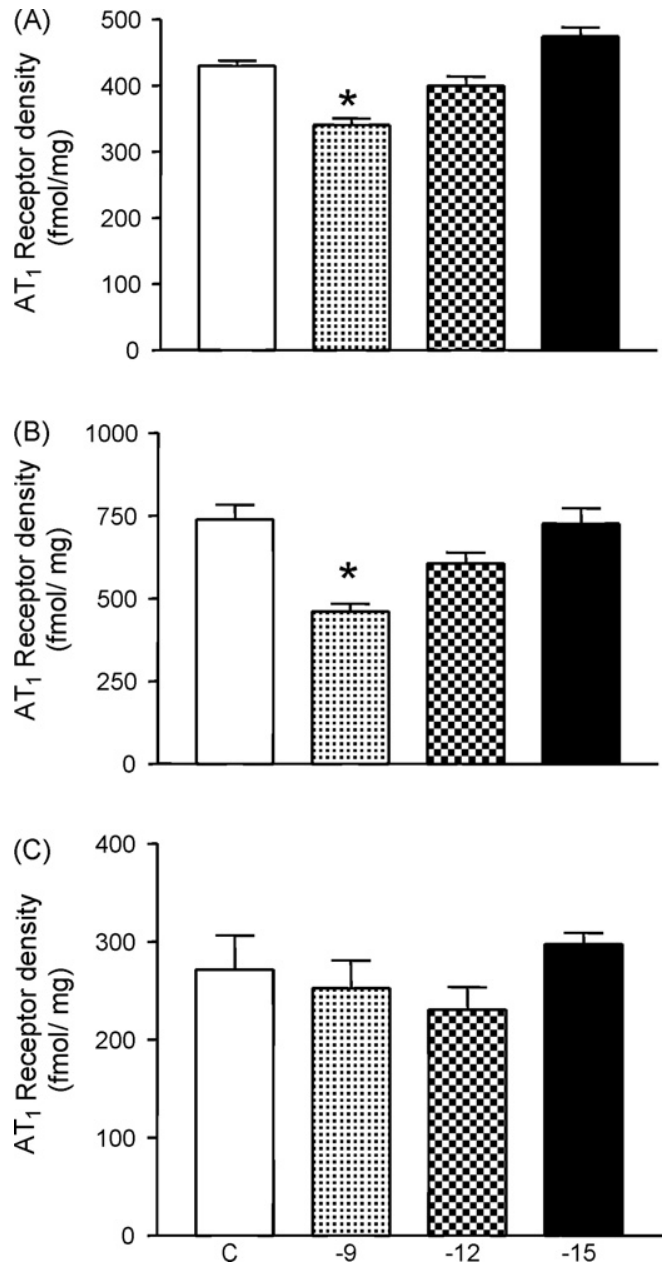

Fig. 3 - $\mathrm{AT}_{1}$ receptor density in kidney of WKY (A), SHR (B) and STZ-induced diabetic rats (C) pre-treated with DAA-I, respectively. The bars represent the mean value \pm S.E.M. of four to five experiments. Empty bar represent control groups and the shaded bars represents groups treated with graded concentrations $\left(10^{-9} \mathrm{M}, 10^{-12} \mathrm{M}\right.$ and $\left.10^{-15} \mathrm{M}\right)$ of DAA-I. *Indicates significant difference from respective control group $(p<0.05)$.

STZ-induced diabetic and WKY, respectively). The effects of DAA-I $\left(10^{-9} \mathrm{M}\right.$ to $\left.10^{-15} \mathrm{M}\right)$ on the renal $\mathrm{AT}_{1}$ mRNA expression are shown in Fig. 5. DAA-I did not significantly alter the level of $\mathrm{AT}_{1}$ mRNA in the kidney of WKY, SHR and STZ-induced diabetic rats.

\subsection{Western blotting}

The $\mathrm{AT}_{1}$ receptor antibody has a molecular weight of $43 \mathrm{kDa}$. The expression of $\mathrm{AT}_{1}$ receptor protein in the kidney of WKY, SHR and STZ-induced diabetic rats is shown in Fig. 6. Compared to the WKY, there was an increase in $\mathrm{AT}_{1}$ receptor protein in the SHR and a decrease in the STZ-induced diabetic rats. The effects of DAA-I $\left(10^{-9} \mathrm{M}\right.$ to $\left.10^{-15} \mathrm{M}\right)$ on the expression of $\mathrm{AT}_{1}$ receptor protein in the kidney of WKY, SHR and STZinduced diabetic rats are shown in Fig. 7. Ninety minutes of perfusion with DAA-I perfusion did not affect the $\mathrm{AT}_{1}$ receptor 


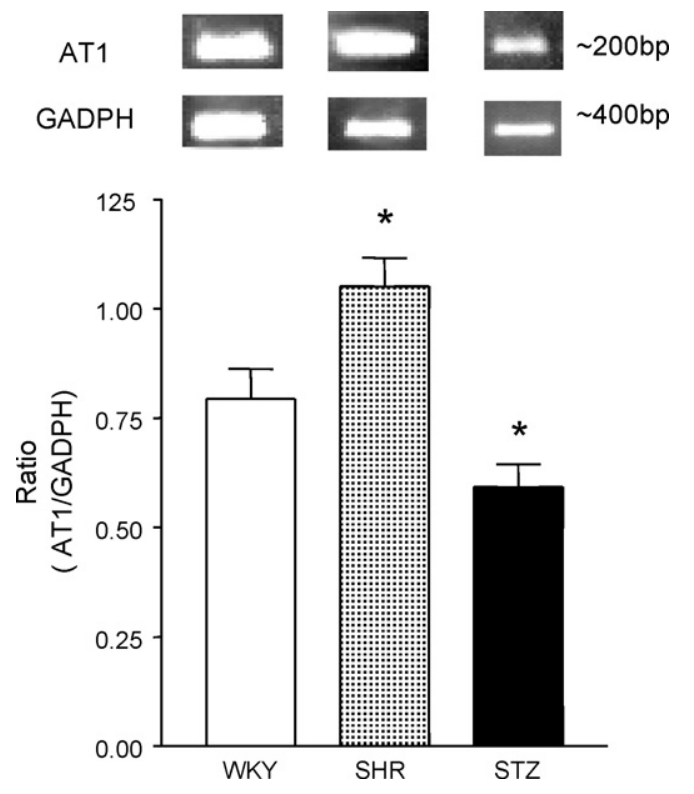

Fig. 4 - $\mathrm{AT}_{1}$ mRNA expression level in the kidney of $\mathrm{WKY}$, SHR and STZ-induced diabetic rats: $(A)$ agarose gel electropherogram of $\mathrm{AT}_{1}$ and GAPDH cDNA; (B) quantification of $A_{1}$ mRNA (normalized against GADPH mRNA). The bars represent the mean \pm S.E.M. of three to four rats. *Indicates significant difference from the WKY value $(p<0.05)$.

expression in the kidney for WKY, SHR and STZ-induced diabetic rats.

\section{Discussion}

\subsection{Profile of renal angiotensin receptor}

In the present study, homologous competitive binding assay performed with specific $\mathrm{AT}_{1}$ receptor antagonist, losartan and the $\mathrm{AT}_{2}$ receptor antagonist, $\mathrm{PD} 123319$ revealed that the $\mathrm{AT}_{1}$ receptor was the main angiotensin receptor subtype present in the kidney membrane. Several binding studies have also shown exclusive presence of $\mathrm{AT}_{1}$ receptors in the renal glomeruli, tubular and outer medullary membranes of Sprague-Dawley rats [14,15]. Autoradiographic techniques have also localized a predominant expression of $\mathrm{AT}_{1}$ receptor in the adult rat kidneys [11]. RT-PCR and Western blot analysis have additionally showed a predominance of $\mathrm{AT}_{1}$ receptor localization in the rat kidneys $[21,24,36]$.

The binding study also shows that $\mathrm{AT}_{1}$ receptor density was significantly higher in the SHR compared to the WKY rats. The finding supports those of earlier investigators $[5,16,17]$. These authors have correlated the increase in $\mathrm{AT}_{1}$ receptor to the enhancement of angiotensin II-induced renal contractility. The receptor affinity $\left(K_{\mathrm{d}}\right)$ for the $\mathrm{AT}_{1}$ receptor remained unchanged in the WKY and SHR animals. The lack of alteration in $\mathrm{AT}_{1}$ receptor affinity in hypertensive animals have also been reported by other authors [7,17]. RT-PCR and Western blot analysis are in agreement with the result from the receptor binding assay. Increases in $\mathrm{AT}_{1}$ receptor mRNA have been observed in the brain [25,26], aorta [23] and heart of the SHR [20], and glomeruli of stroke-prone SHR [22].

In contrast, the $\mathrm{AT}_{1}$ receptor density in the kidney of STZtreated rats was significantly lower when compared to the density present in the WKY. This reduction mirrors the reduced responsiveness to angiotensin II observed in the perfused kidney in our previous work [13]. Reduction in $\mathrm{AT}_{1}$ receptor density was similarly demonstrated in whole kidney homogenates [5] and glomerulus [2,3,35] of STZ-induced diabetic rats. No significant differences in $\mathrm{AT}_{1}$ receptor affinity was observed between WKY and STZ-treated rats. Similar observations were also documented by other researchers [2,3]. RT-PCR results and Western blot analysis are in agreement the binding data and with our earlier work where a lower $\mathrm{AT}_{1}$ mRNA level was observed in the kidney of STZ-induced diabetic rats. Reduced renal expression of the $\mathrm{AT}_{1}$ receptor has been reported in renal proximal tubules [10] of diabetic SHR animals [4] and diabetic patients [33]. However, a study by Sharma et al. [29] found that kidneys from diabetic rats exhibit decreased expression of the type I inositol triphosphatase receptor $\left(\operatorname{InsP}_{3} \mathrm{R}\right)$ isoform and speculated that the impaired angiotensin II-mediated vasoconstriction in diabetic animals might be caused by down-regulation of InsP $_{3}$ Rs. In a later study, this author showed that $\mathrm{AT}_{1}$ receptor mRNA remains unchanged in aorta from STZ-induced diabetic rats [28]. In contrast, Wehbi et al. [34] showed no significant change of the $\mathrm{AT}_{1}$ receptor but reduced $\mathrm{AT}_{2}$ receptor expression in the kidney of diabetic rats. The different profiles of the angiotensin $\mathrm{AT}_{1}$ receptors seen in diabetic animals reflect the complex metabolic disorder of the disease. In addition, such differences could also be due to the different animal strains and the period used to induce diabetes.

\subsection{Effect of DAA-I on renal $\mathrm{AT}_{1}$ receptor}

Perfusion of the kidney with $10^{-9} \mathrm{M}$ DAA-I significantly reduces $\mathrm{AT}_{1}$ receptor density in both the WKY and SHR kidney membranes. This suggests that the vasodepressor actions of DAA-I may in part be due to a down-regulation of the $\mathrm{AT}_{1}$ receptor in the kidney of WKY and SHR rats. Changes in receptor protein synthesis have been identified as late signalling events, and take hours to occur [32]. As DAA-I was perfused into the kidneys for more than $1 \mathrm{~h}$; it is possible that an adequate concentration of the nonapeptide could downregulate the $\mathrm{AT}_{1}$ receptors. However, the RT-PCR and Western blot analysis did not show down-regulation of $\mathrm{AT}_{1}$ receptors as there were no changes in gene and protein expression with pre-treatment of $10^{-9} \mathrm{M}$ DAA-I concentration. It is possible that the reduced $\mathrm{AT}_{1}$ receptor density observed at $10^{-9} \mathrm{MDAA}-$ I may be due to receptor internalization.

Receptor internalization leads to a reduction in the number of receptors present on the membrane surface [27]. This may explain the findings from our binding assay as DAA-I may have repositioned the $\mathrm{AT}_{1}$ receptor into the membrane and lysis of the membrane for Western blot may have exposed the internalized receptors. Agonist-induced receptor internalization especially of $\mathrm{AT}_{1}$ receptor has been reported $[12,18]$. Studies on endogenous $\mathrm{AT}_{2}$ receptors have demonstrated that it is an internalization-deficient receptor [18]. Internalization 

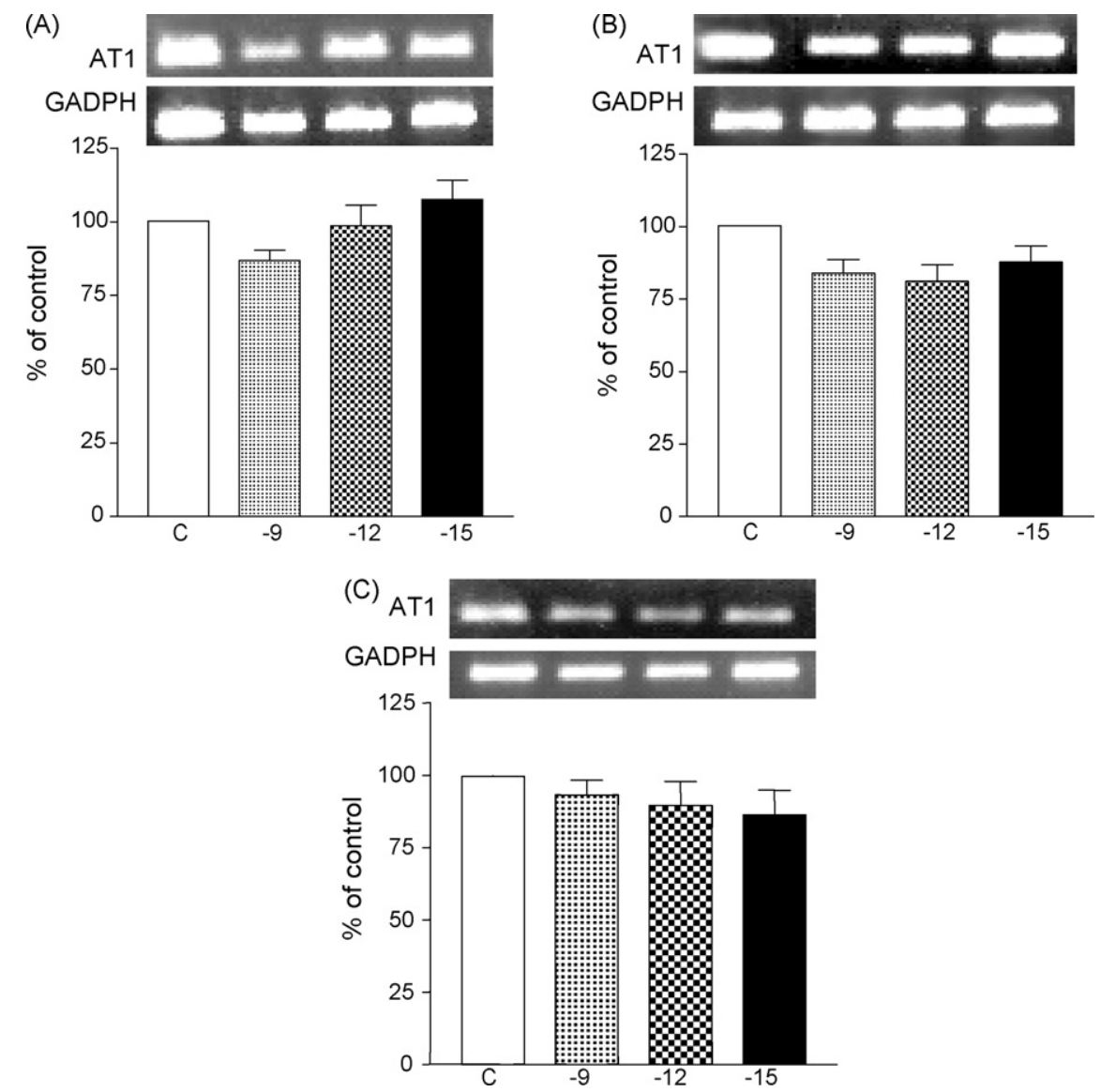

Fig. 5 - Effect of DAA-I on the expression of $A T_{1}$ mRNA in perfused kidney of WKY (A), SHR (B) and STZ-induced diabetic rats (C). Above each bar chart is the respective agarose gel electropherogram of AT $_{1}$ and GADPH cDNA. The bars represent the mean value \pm S.E.M. of four to five experiments. Empty bars represent control groups and the shaded bars represent groups treated with graded concentrations $\left(10^{-9} \mathrm{M}, 10^{-12} \mathrm{M}\right.$ and $\left.10^{-15} \mathrm{M}\right)$ of DAA-I. Each bar is expressed as a percentage of the control. *Indicates significant difference from respective control group $(p<0.05)$.

(a)
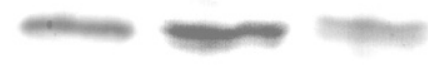

$43 \mathrm{kDa}$

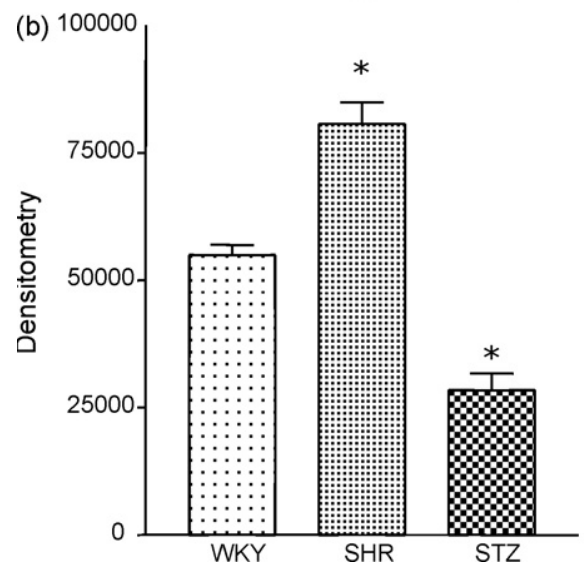

Fig. 6 - $\mathrm{AT}_{1}$ receptor expression levels in the kidney of WKY, SHR and STZ-induced diabetic rats: (A) Western blot of $\mathrm{AT}_{1}$ receptor; (B) densitometric quantification of $\mathrm{AT}_{1}$ receptor level. The bars represent the mean \pm S.E.M. of three rats. *Indicates significant difference from the WKY value $(p<0.05)$. of the $\mathrm{AT}_{1}$ receptor may explain the vasodepressor actions observed earlier in the isolated perfused kidneys of WKY and SHR animals.

Pre-treatment with $10^{-12} \mathrm{M}$ and $10^{-15} \mathrm{M}$ DAA-I did not affect the $\mathrm{AT}_{1}$ receptor density although reduction in contractility was observed in the ex vivo renal study [13]. A slight reduction in receptor density was seen in $10^{-12} \mathrm{M}$ pretreated kidneys especially in the SHR. A similar pattern was also observed with RT-PCR and Western blot analysis. At these subphysiological concentrations, a small difference in receptor availability could still contribute to the observed attenuation of angiotensin II contraction. It is also possible that DAA-I binds to the $\mathrm{AT}_{1}$ receptor and activate different second messenger pathways, which contributed to its vasodepressor actions. In such a scenario, internalization of the $\mathrm{AT}_{1}$ receptors is a normal negative feedback mechanism occurring at concentrations above paraphysiological level and absent at lower concentrations.

Pre-treatment with DAA-I did not affect the renal $\mathrm{AT}_{1}$ receptor density in STZ-treated kidney. This perhaps explains our earlier result, where DAA-I had no effect on angiotensin IIinduced vasoconstriction in STZ-induced diabetic rat kidney [13]. The actual underlying mechanisms for this absence of 

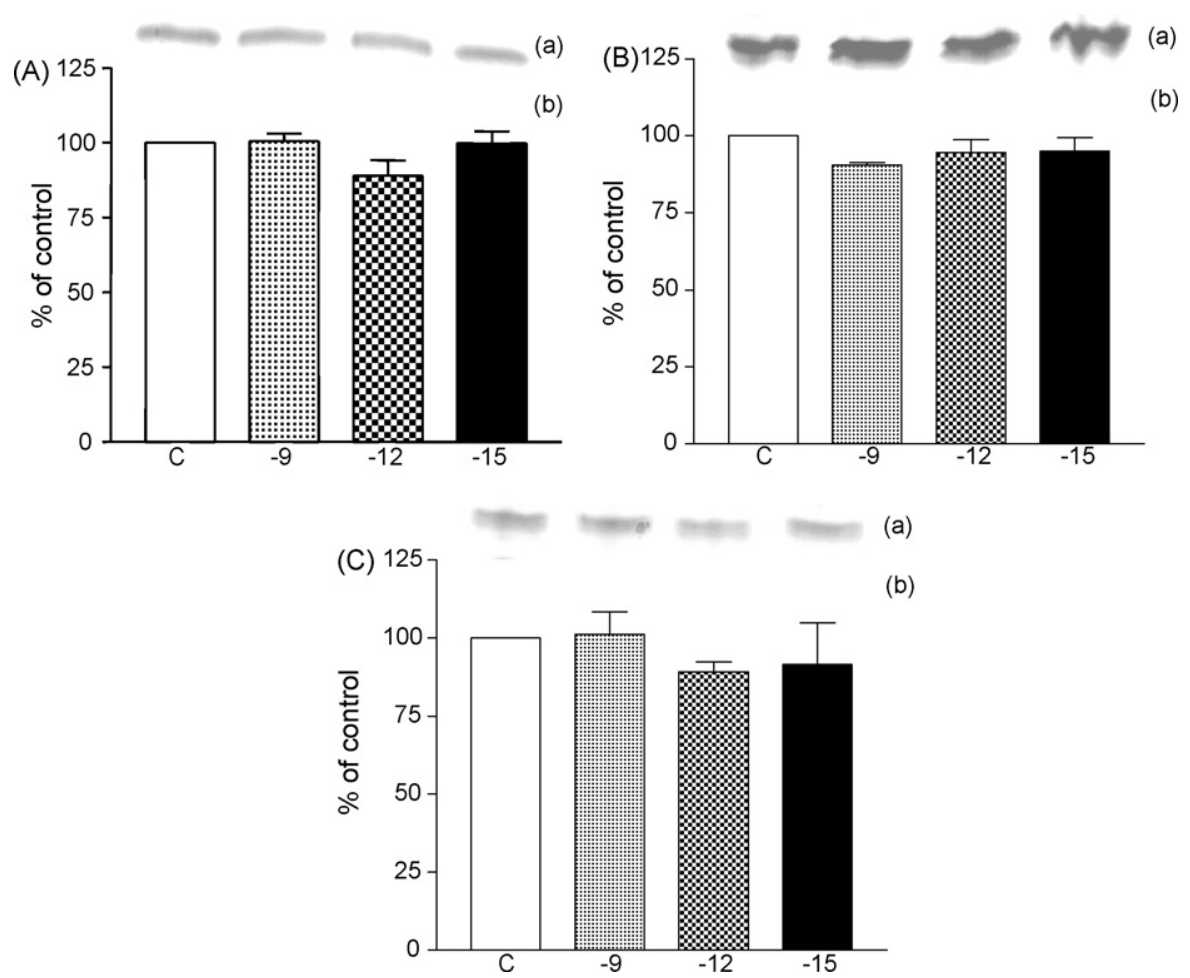

(a)

(b)

Fig. 7 - Effect of DAA-I on the expression of $A_{1}$ receptor levels in perfused kidney of WKY (A), SHR (B) and STZ-induced diabetic rats (C). Above each bar is the respective blot for $\mathrm{AT}_{1}$ receptor. Empty bars represent control groups and the shaded bars represent groups treated with graded concentrations $\left(10^{-9} \mathrm{M}, 10^{-12} \mathrm{M}\right.$ and $\left.10^{-15} \mathrm{M}\right)$ of DAA-I. Each bar represents the mean \pm S.E.M. of three rats and expressed over its control. ${ }^{*}$ Indicates significantly different from its control value $(p<0.05)$.

effects are not known. In agreement with the binding assay, no changes in $\mathrm{AT}_{1}$ receptor gene and protein expression was seen in the STZ-induced diabetic rat kidney. As structural changes occur during the diabetes, it is possible that the binding site for DAA-I at $\mathrm{AT}_{1}$ receptor may be altered, thus reducing the ability of DAA-I to bind to $\mathrm{AT}_{1}$ receptor. A slightly lower $\mathrm{AT}_{1}$ receptor affinity was detected in the STZ-induced diabetic untreated and DAA-I treated animals compared to the WKY. No significant difference in receptor affinity was observed between the DAA-I treated group with its own control further suggests that the DAA-I binds to other binding site than Ang II to modulate the $\mathrm{AT}_{1}$ receptors.

In summary, the present finding demonstrated the accompanying changes in $\mathrm{AT}_{1}$ receptor profile following effective vasomodulatory concentrations of DAA-I in the kidneys of WKY and SHR. The data support the contention that DAA-I acts via the $\mathrm{AT}_{1}$ receptor in that it internalizes the receptors in these two animal strains and not in the STZ-induced diabetic rats where DAA-I has no vasodepressor action.

\section{REFEREN CES}

[1] Abd Jalil R, Haider HK, Sim MK, Ding PZ, Ramos LB, Jiang S, et al. Cardioprotective effect of des-aspartate-angiotensin I (DAA-I) on cytokine gene expression profile in ligation of model of myocardial infarction. Life Sci 2006;78:341-51.
[2] Amiri F, Garcia R. Renal angiotensin II receptors and protein kinase $C$ in diabetic rats: effects of insulin and ACE inhibition. Am J Physiol Renal Physiol 2000;278:F603-12.

[3] Ballermann BJ, Skorecki KL, Brenner BM. Reduced glomerular angiotensin II receptor density in early untreated diabetes mellitus in the rat. Am J Physiol 1984;247:F110-6.

[4] Bonnet F, Candido R, Carey RM, Casley D, Russo LM, Osicka $\mathrm{TM}$, et al. Renal expression of angiotensin receptors in long term diabetes and the effects of angiotensin 1 receptor blockade. J Hypertens 2002;20:1615-24.

[5] Brown L, Wall D, Marchant C, Sernia C. Tissue-specific changes in angiotensin II receptors in streptozotocindiabetic rats. J Endocrinol 1997;154:355-62.

[6] Carmines PK, Morrison TK, Navar LG. Angiotensin II effects on microvascular diameters of in vitro blood-perfused juxtamedullary nephrons. Am J Physiol 1986;251:F610-8.

[7] Chatziantoniou C, Arendshorst WJ. Angiotensin and thromboxane in genetically hypertensive rats: renal blood flow and receptor studies. Am J Physiol 1991;261: F238-47.

[8] Chatziantoniou C, Arendshorst WJ. Angiotensin receptor sites in renal vasculature of rats developing genetic hypertension. Am J Physiol 1993;265:F853-62.

[9] Chen WS, Sim MK. Effects of des-Asp-angiotensin I on the expression of $\mathrm{AT}_{1}$ and $\mathrm{AT}_{2}$ receptors in ventricles of hypertrophic rat hearts. Regul Pept 2004;117:207-12.

[10] Cheng HF, Burns KD, Harris RC. Reduced proximal tubule angiotensin II receptor expression in streptozotocininduced diabetes mellitus. Kidney Int 1994;46:1603-10.

[11] Ciuffo GM, Viswanathan M, Selter AM, Tsutsumi K, Saavedra JM. Glomerular angiotensin II receptor subtypes 
during development of rat kidney. Am J Physiol 1993;265:F264-71.

[12] Conchon S, Monnot C, Teutsch B, Corvol P, Clauser E. Internalization of the rat $\mathrm{AT} 1 \mathrm{a}$ and $\mathrm{AT} 1 \mathrm{~b}$ receptors: pharmacological and functional requirements. FEBS Lett 1994;349:365-70.

[13] Dharmani M, Mustafa MR, Achike FI, Sim MK. Effects of des-Asp-angiotensin I on the action of angiotensin II in isolated renal and mesenteric vasculature of normo- and hypertensive and STZ-induced diabetic rats. Regul Pept 2005;129:213-9.

[14] Edwards RM, Aiyar N. Angiotensin II receptor subtypes in the kidney. J Am Soc Nephrol 1993;3:1643-52.

[15] Gauquelin G, Garcia R. Characterization of glomerular angiotensin II receptor subtypes. Receptor 1992;2: 207-12.

[16] Gutkind JS, Kurihara M, Castren E, Saavedra JM. Increased concentration of angiotensin II binding sites in selected brain areas of spontaneously hypertensive rats. J Hypertens 1988;6:79-84.

[17] Haddad G, Garcia R. Characterization and hemodynamic implications of renal vascular angiotensin II receptors in SHR. J Mol Cell Cardiol 1996;28:351-61.

[18] Hunyady L, Catt KJ, Clark AJ, Gaborik Z. Mechanisms and functions of $\mathrm{AT}(1)$ angiotensin receptor internalization. Regul Pept 2000;91:29-44.

[19] Lim BC, Sim MK. Actions of des-Asp angiotensin I on the aortic rings of the normo- and hypertensive rats. Clin Exp Hypertens 1998;20:105-17.

[20] Makino N, Sugano M, Otsuka S, Hata T. Molecular mechanism of angiotensin II type 1 and type 2 receptors in cardiac hypertrophy of spontaneously hypertensive rats. Hypertension 1997;30:796-802.

[21] Miyata N, Park F, Li XF, Cowley Jr AW. Distribution of angiotensin $\mathrm{AT}_{1}$ and $\mathrm{AT}_{2}$ receptor subtypes in the rat kidney. Am J Physiol 1999;277:F437-46.

[22] Obata J, Nakamura T, Takano H, Naito A, Kimura H, Yoshida $\mathrm{Y}$, et al. Increased gene expression of components of the renin-angiotensin system in glomeruli of genetically hypertensive rats. J Hypertens 2000;18:1247-55.

[23] Otsuka S, Sugano M, Makino N, Sawada S, Hata T, Niho Y. Interaction of mRNAs for angiotensin II type 1 and type 2 receptors to vascular remodelling in spontaneously hypertensive rats. Hypertension 1998;32:467-72.

[24] Paxton WG, Runge M, Horaist C, Cohen C, Alexander RW, Bernstein KE. Immunohistochemical localization of rat angiotensin II AT1 receptor. Am J Physiol 1993;264: F989-95.

[25] Raizada MK, Sumners C, Lu D. Angiotensin II type 1 receptor mRNA levels in the brains of normotensive and spontaneously hypertensive rats. J Neurochem 1993;60:1949-52.

[26] Reja V, Goodchild AK, Phillips JK, Pilowsky PM. Upregulation of $\mathrm{AT}_{1}$ receptor and intracellular kinase gene expression in hypertensive rats. Clin Exp Pharmacol Physiol 2006;33:690-5.

[27] Sasamura H, Dzau VJ, Pratt RE. Desensitisation of angiotensin receptor function. Kidney Int 1994;46:1499-501.

[28] Sharma K, Deelman L, Madesh M, Kurz B, Ciccone E, Siva S, et al. Involvement of transforming growth factor-beta in regulation of calcium transients in diabetic vascular smooth muscle cells. Am J Physiol Renal Physiol 2003;285:F1258-70.

[29] Sharma K, Wang L, Zhu Y, Deguzman A, Cao GY, Lynn RB, et al. Renal type I inositol 1,4,5-triphosphate receptor is reduced in streptozotocin-induced diabetic rat and mice. Am J Physiol 1999;276:F54-61.

[30] Sim MK, Min L. Des-aspartate-angiotensin I and angiotensin AT1 receptors in rat cardiac ventricles. Regul Pept 2005;129:133-7.

[31] Sim MK, Yuan HT. Effects of des-Asp-angiotensin I on the contractile action of angiotensin II and angiotensin III. Eur J Pharmacol 1995;278:175-8.

[32] Touyz RM, Schiffrin EL. Signal transduction mechanisms mediating the physiological and pathophysiological actions of angiotensin II in vascular smooth muscle cells. Pharmacol Rev 2000;52:639-72.

[33] Wagner J, Gehlen F, Ciechanowicz A, Ritz E. Angiotensin II receptor type 1 gene expression in human glomerulonephritis and diabetes mellitus. J Am Soc Nephrol 1999;10:545-51.

[34] Wehbi GJ, Zimpelmann J, Carey RM, Levine DZ, Burns KD. Early streptozotocin diabetes mellitus downregulates rat kidney AT2 receptors. Am J Physiol Renal Physiol 2001;280:F254-65.

[35] Wilkes BM. Reduced glomerular angiotensin II receptor density in diabetes mellitus in the rat: time course and mechanism. Endocrinology 1987;120:1291-8.

[36] Zelezna B, Richards EM, Tang W, Lu D, Sumners C, Raizada MK. Characterization of a polyclonal anti-peptide antibody to the angiotensin II type $1\left(\mathrm{AT}_{1}\right)$ receptor. Biochem Biophys Res Commun 1992;183:781-8. 